Article

\title{
Sediment Dynamics of the Neretva Channel (Croatia Coast) Inferred by Chemical and Physical Proxies
}

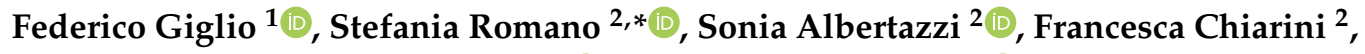 \\ Mariangela Ravaioli ${ }^{2}$, Marco Ligi ${ }^{2}\left(\mathbb{D}\right.$ and Lucilla Capotondi ${ }^{2}$ \\ 1 Istituto di Scienze Polari - Consiglio Nazionale delle Ricerche ISP-CNR, Via P. Gobetti 101, 40129 Bologna, \\ Italy; federico.giglio@cnr.it \\ 2 Istituto di Scienze Marine - Consiglio Nazionale delle Ricerche ISMAR-CNR, Via P. Gobetti 101, \\ 40129 Bologna, Italy; sonia.albertazzi@bo.ismar.cnr.it (S.A.); francesca.chiarini@bo.ismar.cnr.it (F.C.); \\ mariangela.ravaioli@bo.ismar.cnr.it (M.R.); marco.ligi@bo.ismar.cnr.it (M.L.); \\ lucilla.capotondi@bo.ismar.cnr.it (L.C.) \\ * Correspondence: stefania.romano@bo.ismar.cnr.it; Tel.: +39-051-639-8897; Fax: +39-051-639-8940
}

Received: 12 December 2019; Accepted: 21 January 2020; Published: 23 January 2020

\begin{abstract}
We examined the transport of sediments and their surficial pathways from the mouth of Neretva River, through the Neretva Channel, toward the Adriatic Sea. This research was based on twelve box-cores and five grab samples collected within the Neretva Channel. Sediment dynamics were evaluated using several proxies, such as organic matter, radiochemical isotopes and select metal concentrations and physical parameters. The data analysis showed that the influence of the river on particle distribution along the Neretva Channel decreases northward, with an estimated sediment accumulation rate ranging from 1.9 to $8.5 \mathrm{~mm} / \mathrm{yr}$. The lowest accumulation rate was found in the sector not influenced by river inflow, whereas the preferential sediment accumulation area is in the center of the basin. We speculate that dispersion and accumulation of sediments are both driven by an eddy in the waters of the Neretva Channel triggered/or intensified seasonally by the interaction of karstic springs, river input and Adriatic Sea waters. Our results indicate that the anthropogenic factor does not affect the concentration of metals within the channel and that the river particles dynamics determine the $\mathrm{Pb}$ areal distribution, while $\mathrm{Cr}$ and $\mathrm{Ni}$ have a possible source located to the northwest of the river-mouth.
\end{abstract}

Keywords: Adriatic Sea; Neretva Channel; sediment dynamics; age model; metal concentrations

\section{Introduction}

The legal instruments of EU's Environmental policies and their regional and local application levels provide an interrelated regulatory framework for protection, preservation and prevention of the European oceans [1-4]. According to these European directives, they are intended to apply an ecosystem-based approach to manage human activities whilst ensuring sustainable use of marine goods and services (respectively) [4,5]. In particular, the Marine Strategy Framework Directive (MSFD) [3] uses eleven descriptors with several indicators covering ecological, physical, chemical and anthropogenic components of the ecosystems that need to be integrated to achieve a good environmental status [6]. In this context, the study of sediment dynamics plays an important role, as it provides the basic knowledge for a correct evaluation of the environmental quality.

The Adriatic Sea is an important sub-region of the Mediterranean marine area and has been proposed as Ecologically or Biologically Significant Areas in the Mediterranean (EBSAs) from the Barcelona Convention, UNEP/MAP [7]. Several studies were carried out on sediment dynamics and geochemistry in the Adriatic Sea, but they were mainly focused on its western side (Italian 
Economic Water Zone; see [8-14] and reference therein). Hence, few geochemical data are available from sedimentary deposits of the eastern coast [15-17] and potential input of contaminants is still little known.

Regional geology largely controls the composition of marine sediments; however, in densely populated regions, such as coastal areas, the anthropogenic influence may strongly affect the dispersion and concentration of organic matter and contaminants, modifying the river discharge through a combination of factors such as urban settlements and roads, runoff of agricultural soils, and dry and wet atmospheric deposition [18]. In this work, the influence of the Neretva River (NR) on the southern Croatian Adriatic coastal system was investigated in order to gain information on sediment dynamics of the area (Figure 1).

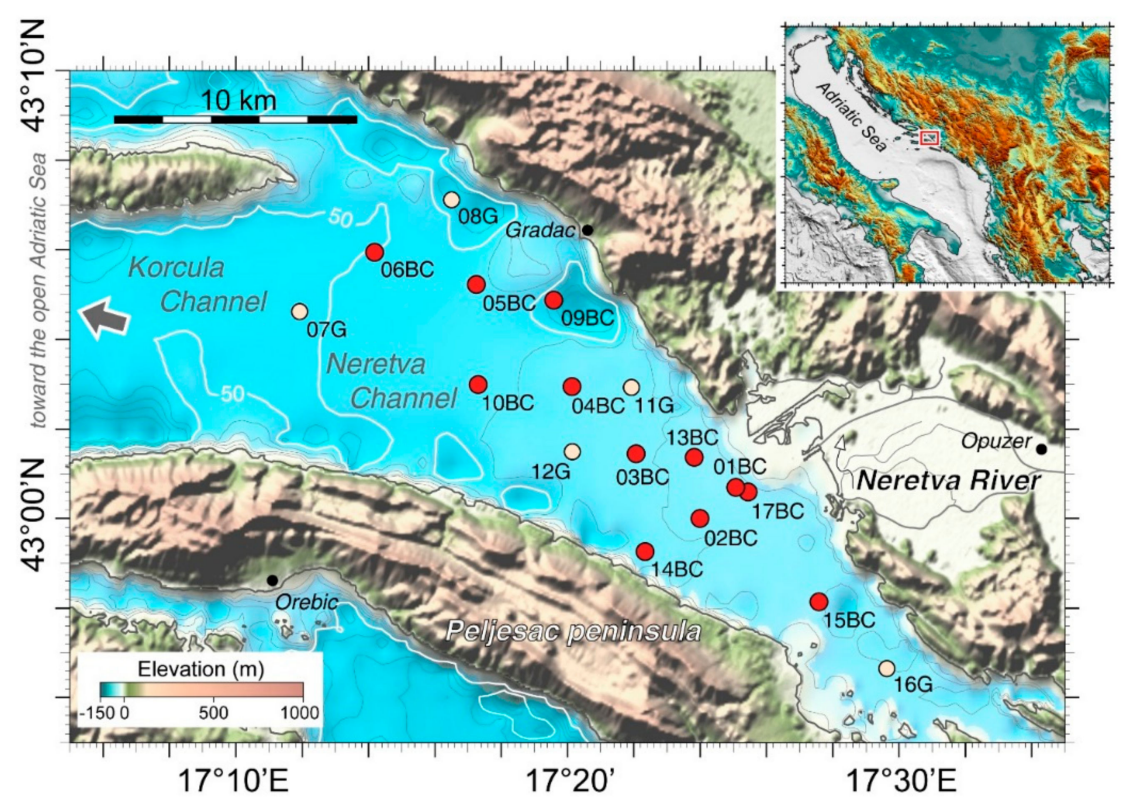

Figure 1. Study area and sampling locations. Shaded relief image derived from bathymetric data with sun illumination from NW, $45^{\circ}$ over the horizon and no vertical exaggeration (grid resolution $10 \mathrm{~m}$ ). Elevation and bathymetry data from EMODnet gridded data (www.emodnet.eu/bathymetry). Filled red and pink circles indicate box corer and grab samples locations, respectively. Bathymetry contour interval is $10 \mathrm{~m}$. Red box in the inset indicates the study area.

The major aim of this work was to determine sediment pathways and dynamics of particles that bond metals in the Neretva Channel (NC) by combining sediment geochemistry, geochronological data and physical parameters of the water column to obtain basic information required for an assessment of the health and quality of the environment to preserve the marine life [19]. These results may provide a useful support for evaluation and decision-making processes aiming to achieve the environmental goals proposed by the Water Framework Directive [2] and the MSFD [3].

\section{Study Area}

The NC (Figure 1) is a narrow, semi-enclosed basin located along the southernmost part of the Croatian coast. Oriented SE-NW, it is bounded to the NE by the Croatian coastline, to the NW by the open Adriatic Sea through the Korcula Channel, and to the SW by the Peljesac Peninsula. The NC is a microtidal, low-wave energy environment with river-dominated sedimentation processes $[15,17]$. The river has an average annual water inflow of $332 \mathrm{~m}^{3} / \mathrm{s}$ with peaks in December and April, and with a long-term seasonal variability in terms of minimum and maximum monthly discharge from low to moderate, respectively [20]. The NR mouth, located $\approx 20 \mathrm{~km}$ to the east of the town of Metković, is characterized by a reclaimed alluvial plain and forms the largest depositional system in the southern Croatian coast, covering an area of $\approx 246 \mathrm{~km}^{2}$. 
The NR, despite high annual precipitation in the catchment area, has a low stream density because part of its water is collected into karstic aquifers [20]. Furthermore, five hydropower plants in the Neretva catchment impound a total area of $36 \mathrm{~km}^{2}$, storing a $1.1 \mathrm{~km}^{3}$ water reserve [21]. As a consequence, the present-day delta is not associated with the large volumes of deposits that other river systems along the western Adriatic coast are. Finally, water regime in the lower course of the NR is complicated by the interaction with seawater ingression. For instance, deepening of the NR riverbed may cause higher salinity of both water and soil due to a drop in the ground water level $[17,22]$. Salt water constantly penetrates into underground waterways, leading to the salinity of the soil, particularly during the dry season when the river flow is reduced [23]. Hence, the natural environment of the lower river course may be strongly threatened in terms of chemical, physical and biological changes [17], especially where human activities cause pressure, such as road construction sites, urbanization, hunting and mining [22,24,25]. Moreover, the NR is moderately affected by untreated municipal and industrial (metallurgy and other lighter activities) wastewaters.

\section{Materials and Methods}

During the oceanographic cruise NERES06 onboard the R/V Bios DVA in May 2006, twelve box cores (BC) and five grab samples (G) were collected in the study area (Figure 1). Sampling sites were selected along three transects parallel to the NW-SE-oriented axis of the channel in order to obtain an exhaustive coverage of the investigated area.

The $\mathrm{BC}$ short cores ( $\approx 20 \mathrm{~cm}$ long) were radiographed via a directional X-ray tube (M60 Gilardoni) using an aluminum and PVC filter, allowing the identification of the sedimentary structures before sub-sampling. Once the cores were opened, sediments were described for visual characteristics, and then, one-half of each was stored for the historical archive and the other half was sub-sampled with a frequency of $2 \mathrm{~cm}$ for sediment grain size and tracer determinations. Before analyses, sediments were dried at $60{ }^{\circ} \mathrm{C}$ in order to calculate the sediment porosity assuming a particle density of $2.5 \mathrm{~g} \mathrm{~cm}^{-3}$ [26].

Total carbon (TC) and total nitrogen (TN) contents, and the stable isotopic composition, were determined on the surficial samples by using a FINNIGAN Delta Plus mass spectrometer, directly coupled to the FISONS NA2000 EA (for further details see [27]). The total organic carbon (TOC) was measured by a pre-treatment with $1.5 \mathrm{M} \mathrm{HCl}$ to remove the carbonates. TOC contents are reported as weight percent ( $\mathrm{w} t \%)$ on dry weight. Moreover, $\mathrm{C} / \mathrm{N}$ was calculated as molar ratio between TOC $\%$ and TN\%.

Grain size analysis was carried out on separates following wet sieving on a $63 \mu \mathrm{m}$ mesh-size sieve in order to separate sand from finer fractions, after a pre-treatment with $\mathrm{H}_{2} \mathrm{O}_{2}$ to remove the organic matter and to favor disaggregation between sediment particles. Silt and clay fractions were determined with an X-ray Sedigraph Malvern Mastersizer 2000s.

The time framework was based on ${ }^{137} \mathrm{Cs}$ and ${ }^{210} \mathrm{~Pb}$ radionuclides. ${ }^{137} \mathrm{Cs}$ activity was measured by non-destructive gamma spectrometry (see [28] and references therein) using coaxial intrinsic germanium detectors (Ortec HPGe GMX-20195P and GEM-20200), while ${ }^{210} \mathrm{~Pb}$ was determined by chemical extraction of its daughter ${ }^{210} \mathrm{~Pb}$, assuming secular equilibrium between the two isotopes [11,29].

In order to determine the metal fraction of surficial sediment particles and/or dissolved in the interstitial water, $0.5 \mathrm{~g}$ of de-frozen wet sediment was leached with $\mathrm{HNO}_{3}$ and $\mathrm{H}_{2} \mathrm{O}_{2}$ (10:3) under reflux [30].

$\mathrm{Cr}, \mathrm{Ni}$ and $\mathrm{Pb}$ concentrations were determined by furnace atomic absorption spectrophotometers and the results were normalized to the sediment dry weight. Accuracy and precision were tested through repeated analysis of certified reference material NIST 2709, and in comparison with the reported values for the determination of labile or extractable elements. Results fell within the range of certified values. Accuracies (as \%RDS), estimated by replicate analyses of NIST 2709 , were $4 \%$ (for Ni and $\mathrm{Cr}$ ) and $3 \%$ (for $\mathrm{Pb}$ ). The leaching recoveries, calculated on the basis of certified values for total concentrations, were $66 \%, 63 \%$ and $93 \%$ for $\mathrm{Pb}, \mathrm{Cr}$ and $\mathrm{Ni}$, respectively. 
Conductivity and temperature (CTD) data collections were carried out during the oceanographic cruise by correspondence with sampling stations with a Sea-Bird SBE 25 CTD equipped with temperature and conductivity sensors. The CTD data were processed according to UNESCO standards [31], and pressure values were averaged at 0.5 dbar intervals. The Ocean Data View software was used to interpolate spatially the CTD vertical profiles [32].

The areal distributions of metal contents, sand fraction and sediment accumulation rate (SAR) were computed by universal kriging interpolation, a method for which the values are modelled by a Gaussian process governed by prior covariance. Under suitable assumptions on the spatial continuity of the variable to interpolate, kriging gives the best linear unbiased prediction of the interpolated values [33]. Spatial continuity parameters (range, nugget and sill) were evaluated using theoretical models fitting the experimental variograms calculated for each variable $[34,35]$. Universal kriging assumes that a continuous property called "regionalized variable" consists of two parts: a drift, or expected value, and a residual, or deviation from the drift. The drift is modelled by a polynomial function within a given neighborhood. The residual surface obtained by drift removal can be regarded as first-order stationary in a statistical sense. However, the effectiveness of this technique depends on the correct specification of several parameters that describe the semivariogram and the model of drift. We assumed a linear model of the semivariogram implying that estimation error increases without bounds with increasing distance from the control point.

Spatial analysis and mapping were performed using the PLOTMAP [36] and the GMT [37] software packages adopting the WGS84 datum and a Mercator projection with standard parallel at the latitude of $42.5^{\circ} \mathrm{N}$.

Data relationships were statistically analyzed through the Pearson correlation coefficient, using the STATISTICA software package.

\section{Results}

\subsection{Sediment Features}

Sediment grain size analyses indicate that the NC deposits are mostly clayey silts with a silty dominant fraction and a low-fraction of sand. In particular, on surficial samples, the coarser materials were found in the southernmost zone (sand content of 31\% in site 15BC) and in the north-western sector of the channel (sand fractions of $51 \%, 39 \%$ and $31 \%$ at sites $07 \mathrm{BC}, 06 \mathrm{BC}$ and $10 \mathrm{BC}$, respectively; Figure 2a). 

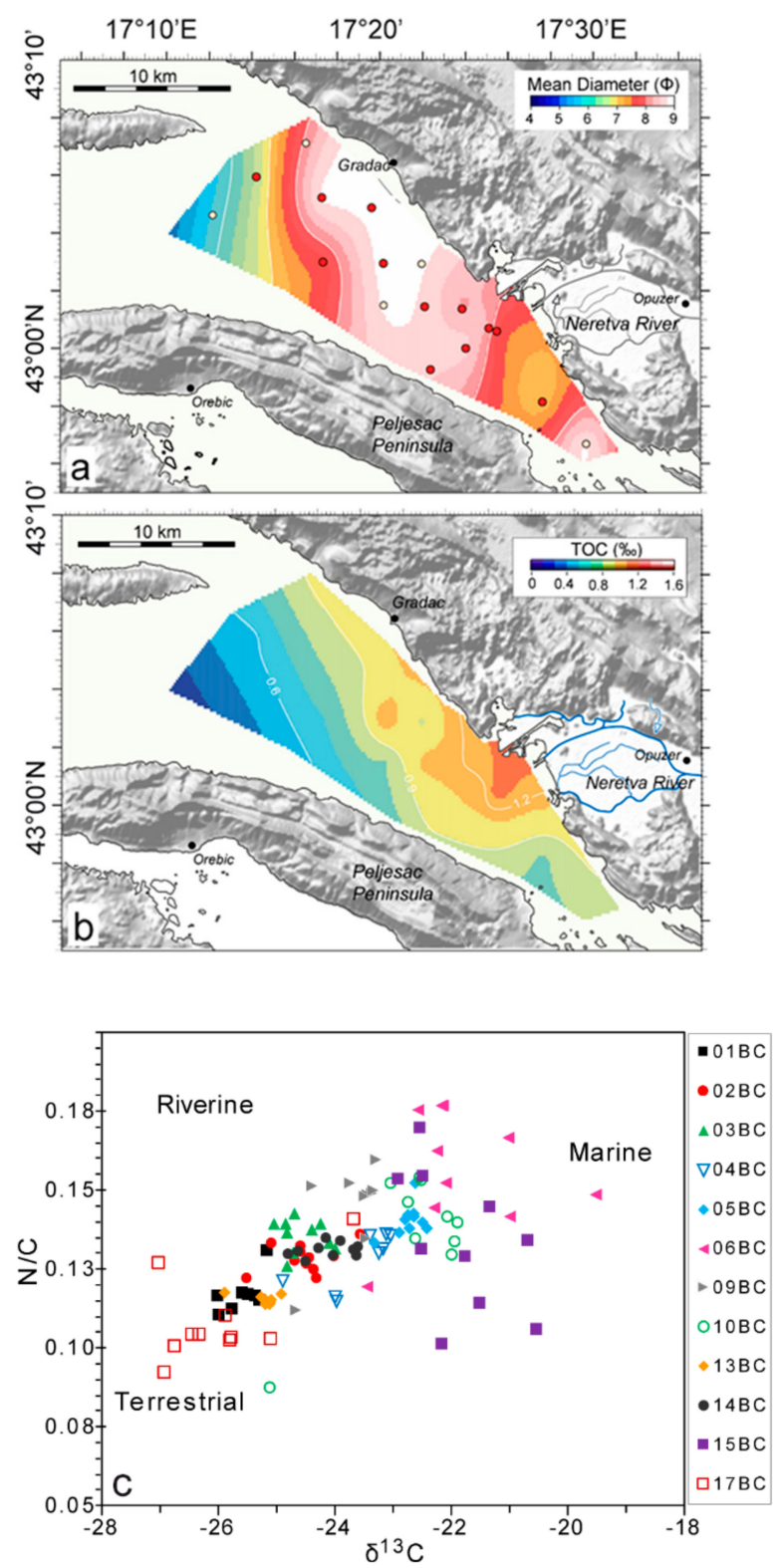

Figure 2. (a) Log-normal sediment mean diameter [38] areal distribution and (b) organic carbon surficial areal distribution in the Neretva Channel with (c) covariation of N/C versus $\delta^{13} \mathrm{C}$.

Surficial TOC (Figure $2 \mathrm{~b}$ ) varies from $0.6 \%$ (06BC) to $1.18 \%$ (17BC) and $\delta^{13} \mathrm{C}$ from $-22.3 \%$ o (06BC) to $-27.0 \%$ o (17BC). Total nitrogen (TN) content ranges from $0.15 \%$ (17BC) to $0.09 \%(06 \mathrm{BC})$, resulting in $\mathrm{C} / \mathrm{N}$ ratios from 5.9 to 8.5 .

X-radiograph images, together with depth distributions of sediment porosity and sand fractions of selected BC samples, are shown in Figure 3. X-ray images of BCs do not display evident inner sedimentary structures; instead, bioturbations are observed in several sediment intervals; in particular, in cores from the area close to the river mouth (i.e. site 01BC). Sample porosities of the surficial level along the entire channel range between 0.62 and 0.71 . In addition, at each sampling site porosity slightly decreases with depth (toward the bottom of the $\mathrm{BC}$ ) without abrupt changes through the sedimentary sequence (Figure 3 ). 

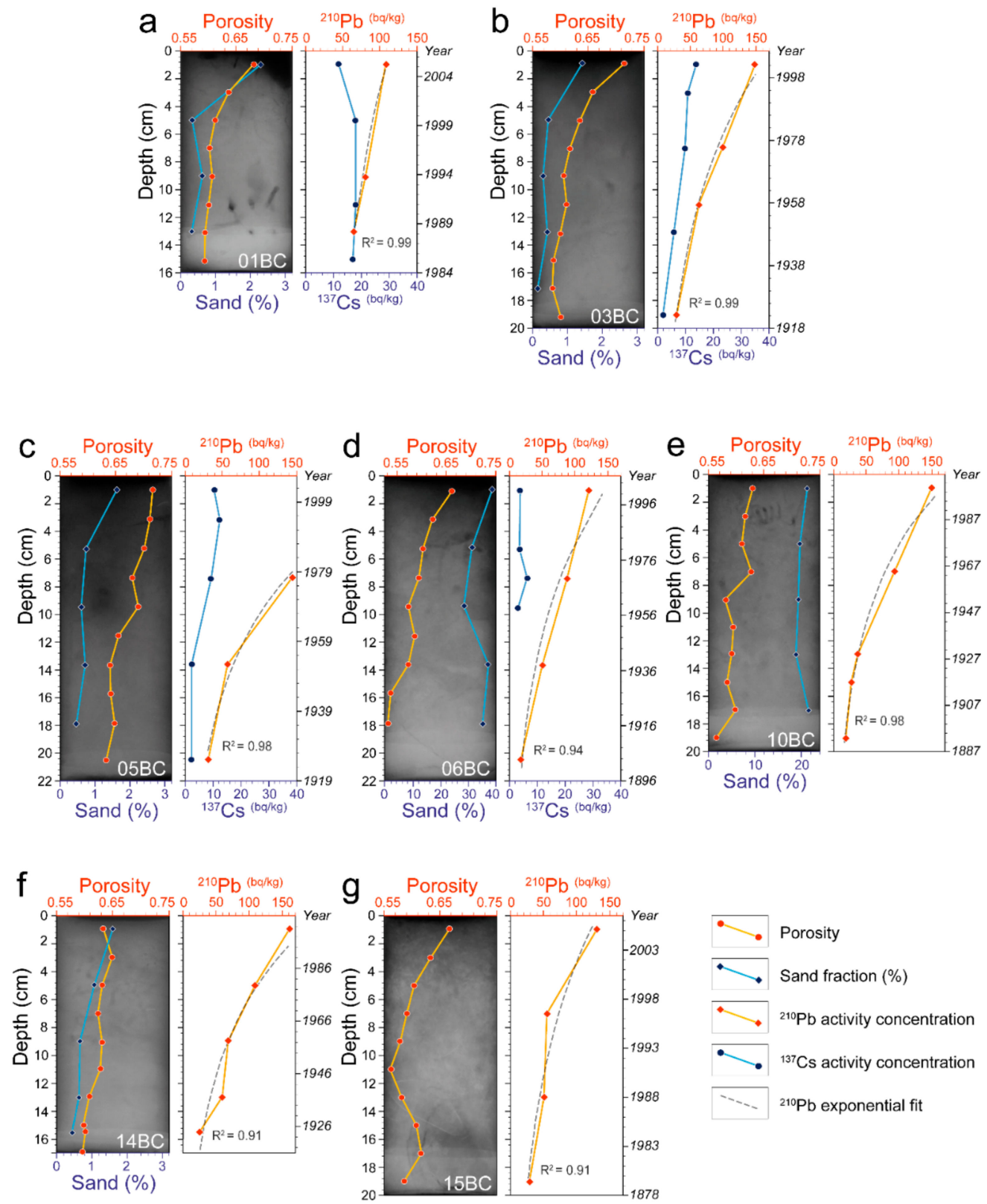

Figure 3. Examples of X-ray images, porosity and sand content depth profiles (left panel), and ${ }^{210} \mathrm{~Pb}$ and ${ }^{137} \mathrm{Cs}$ concentration activity variations with depth (right panel) from selected box cores (BCs): (a) 01BC; (b) 03BC; (c) 05BC; (d) 06BC; (e) 10BC; (f) 14BC and (g) 15BC.

Vegetal remains are found mostly in sediments near the river mouth (sites 01BC, 02BC, 09BC and $15 \mathrm{BC}$ ), whereas fragments of molluscs, bryozoans and ostracods are widespread in the surficial sediments of the NC, with the exception of the nearest site to the river mouth (01BC), where only fragments of molluscs are found, and of the deepest site $(07 \mathrm{G})$ where the benthic macrofauna is almost absent.

\subsection{Activity-Depth Profile of ${ }^{210} \mathrm{~Pb}$ and ${ }^{137} \mathrm{Cs}$ Radionuclides}

${ }^{137} \mathrm{Cs}$ and ${ }^{210} \mathrm{~Pb}$ content variations with depth of selected $\mathrm{BC}$ are shown in Figure $3 .{ }^{137} \mathrm{Cs}$ measured only in three BC (Figure 3a-d), displays maximum activity concentration at the top of BCs (i.e. 01BC and $03 \mathrm{BC}$ or at sub-surficial levels as in $02 \mathrm{BC}$ and $05 \mathrm{BC}$; Figure $3 \mathrm{a}, \mathrm{c}$ ) with values ranging from the detection limit to $18 \mathrm{~Bq} / \mathrm{kg}$ (Figure 3d,e). Unfortunately, the 1986 peak of ${ }^{137} \mathrm{Cs}$ relative to the Chernobyl accident cannot be resolved in our samples. 
${ }^{210} \mathrm{~Pb}$ contents in cores generally decrease with depth following a regular exponential trend (Figure 3). Since cores $04 \mathrm{BC}, 09 \mathrm{BC}, 13 \mathrm{BC}, 14 \mathrm{BC}$ and 15BC are strongly affected by physical or biological mixing (see $\mathrm{X}$-radiograph; i.e. Figure $3 \mathrm{f}, \mathrm{g}$ ), a different ${ }^{210} \mathrm{~Pb}$ pattern is observed.

\subsection{Regional Water Circulation and Water-Column Structure}

During the sampling survey, temperature $(\mathrm{T})$ and salinity $(\mathrm{S})$ values in the water column ranged from 12.7 to $17.1^{\circ} \mathrm{C}$ and from 19.2 to $38.0 \mathrm{psu}$, respectively (Figure 4a,b). At sites 01BC and 17BC, in front of the river mouth, recorded values of $\mathrm{T}$ and $\mathrm{S}$ at sea surface were $\approx 16$ and $15.2^{\circ} \mathrm{C}$, and $\approx 34$ and 19.3 psu respectively, whereas values at the sea bottom displayed lower temperature and higher salinity ( $\approx 13$ and $13.5^{\circ} \mathrm{C}$, and $\approx 37.5$ and 37.6 psu respectively).
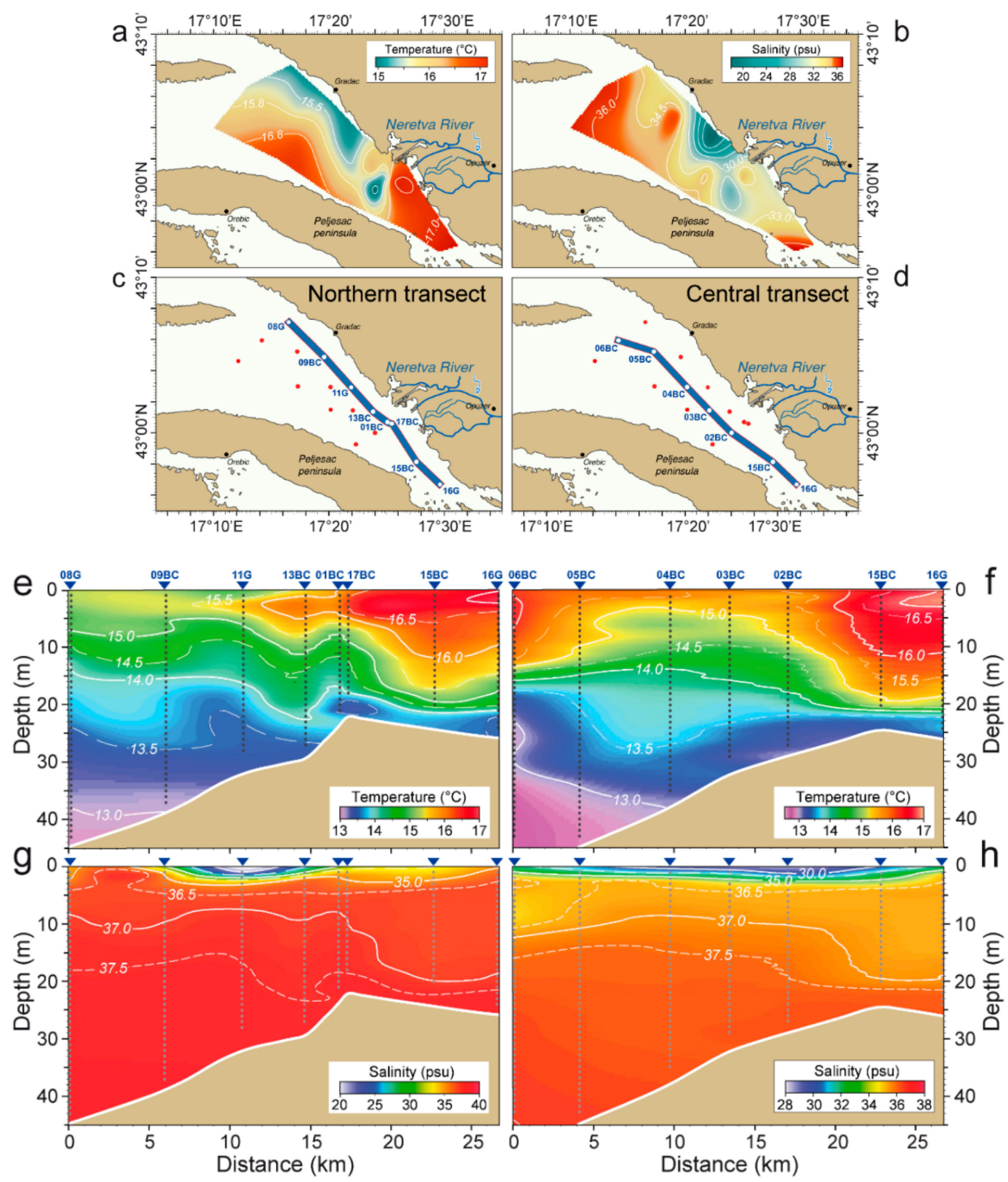

Figure 4. (a) Temperature and (b) salinity spatial distribution. Temperature (e,f) and salinity (g,h) vertical cross sections along the northern $(\mathbf{c})$ and the central (d) transects running parallel to the NE coast of the Neretva Channel.

$\mathrm{T}$ and S profiles across the water column are shown in Figure $4 \mathrm{e}-\mathrm{h}$. Observed values reveal water stratification with the highest temperatures at the surface in the southeast sector of the NC. The northern transect (Figure 4e,f) and surficial areal data (Figure 4a,b) suggest water inflow with lower temperature and salinity localized along the coast to the north of the main Neretva river-mouth 
in the vicinity of station 11G, where a local decrease of salinity has been also recorded at 0 and $5 \mathrm{~m}$ water-depth intervals (Figure 4e,h). The water mass with lower T and S moves deeper toward the center of the channel.

\subsection{Metal Distributions}

Among the several metals, we focused on $\mathrm{Cr}, \mathrm{Ni}$ and $\mathrm{Pb}$ in this study, because their origin may be due to both natural and anthropogenic causes. The spatial distributions of their concentrations $(\mu \mathrm{g} / \mathrm{g})$ allowed identifying zones of provenance (source areas) and areas at critical levels (Figure 5). Results shown in Figure 5 indicate that site 08G, in the northern part of the investigated area, displays the maximum contents of $\mathrm{Ni}$ and $\mathrm{Cr}(84.0$ and $71.5 \mu \mathrm{g} / \mathrm{g}$ respectively), whereas the minimum contents were recorded at site $06 \mathrm{BC}$ ( 28.6 and $28.7 \mu \mathrm{g} / \mathrm{g}$, respectively) located in center of the northern sector of the NC (Figure 5b,c). In particular, surficial $\mathrm{Cr}$ and Ni concentrations decrease toward the river mouth. Differently, the $\mathrm{Pb}$ concentrations show two different areas of local maxima: the first ( $36 \mu \mathrm{g} / \mathrm{g}$ ) is located in front of the river mouth at site $01 \mathrm{BC}$; the second $(67.9 \mu \mathrm{g} / \mathrm{g})$ in the center of the NC at site 10BC.
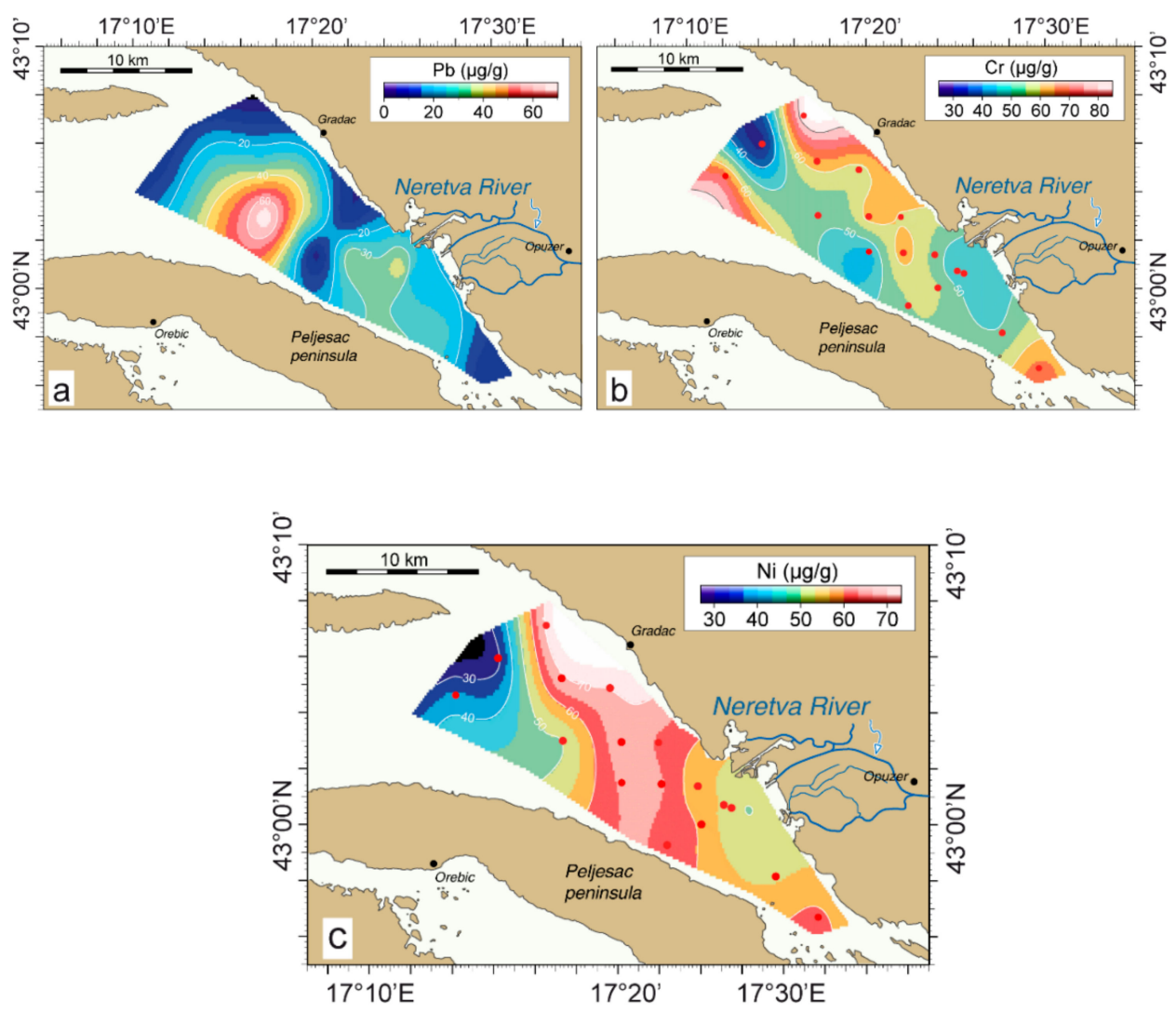

Figure 5. Surficial distribution of (a) $\mathrm{Pb},(\mathbf{b}) \mathrm{Ni}$ and (c) $\mathrm{Cr}$ concentrations.

\section{Discussions}

\subsection{Surface Sediment Distribution}

The Neretva's surficial sediment is generally composed of clayey silt. The distribution suggests an influence of the river plume decreasing along the SE-NW direction (Figure 2a). In particular, accumulation of fine-grained particles (mean grain size $>7.5 \varphi$ [38]) occurs mainly in two areas: in front of the NR mouth and in the central/northeastern part of the NC (Figure 2). This accumulation pattern is in agreement with the observed water circulation, where a hypopycnal river plume formed at the mouth distributes fine-grained particles over the entire channel area $[16,17]$. These observations suggest a different nature of the two observed coarser-grains depositional zones. The southernmost 
zone may only receive river sediments sporadically during events of strong hydro-dynamism in the channel and may be considered a non-depositional area characterized by relict coarser sediment. This silt-sandy accumulation zone was previously reported by [16]. Instead, the northernmost sandy zone may be related to the influence of high energy currents from the open Adriatic Sea that remove the finest part of the sediments.

The observed porosities and particle grain size in the BCs (Figure 3) suggest that over the time recorded by our samples, the NC sedimentation was continuous in a low-energy environment. Moreover, the chaotic textures of sediments in the cores nearest to the river pro-delta area (BC01-17 and 13) suggest also that these deposits are affected by several post-depositional processes, including physical mixing and biological reworking due to microbial activity. Both of those processes may be related to the seasonal river input variability or episodic flooding events from the NR.

\subsection{Organic Carbon}

Relationships between $\mathrm{C} / \mathrm{N}$ ratios and the $\delta^{13} \mathrm{C}$ contents are commonly used as proxies to determine the source of organic matter in coastal areas [26,39,40]. In addition, the $\delta^{13} \mathrm{C}$ and $\delta^{15} \mathrm{~N}$ isotopic compositions and the $\mathrm{N} / \mathrm{C}$ ratio help to discriminate the marine versus terrestrial origins of the particles [41]. Since the photosynthetic processes and carbon sources are different between marine organisms and terrestrial plants, there is an inverse correlation between the $\delta^{13} \mathrm{C}$ and $\mathrm{C} / \mathrm{N}$ ratio: A high $\delta^{13} \mathrm{C}$ values suggests a predominant influence of marine phytoplankton [42]. On the contrary, low $\delta^{13} \mathrm{C}$ values (lower than $-27 \%$ o) are indicative of vegetable sources (C3 plants) from inland; i.e., proximity to the shoreline and/or proximity to a source of organic matter of continental origin [43]. Here, we considered the $N / C$ ratio instead of the $C / N$, because it behaves linearly in a mixing model $[43,44]$ and an estimate of the sedimentary organic carbon fraction is more reliable [45]. The observed N/C and $\delta^{13} \mathrm{C}$ distributions (Figure 2c) indicate that the sites close to the river mouth $(01 \mathrm{BC}$ and $17 \mathrm{BC}$ ) have a clear terrestrial signature due to the strong fluvial input. The marine input increases northward, and the transition between terrestrial and marine regimes may be located along the theoretical line joining sites $12 \mathrm{G}, 4 \mathrm{BC}$ and $9 \mathrm{BC}$ (Figure $2 \mathrm{~b}$ ). In addition, a strong negative correlation $(-0.81)$ is observed between TOC and $\delta^{13} \mathrm{C}$, a result in agreement with that of [17]. These data together with a lack of correlation with the clay fraction (Table 1), suggest riverine ${ }^{13} \mathrm{C}$ depleted terrestrial organic matter as the main source of sedimentary organic carbon [27].

Table 1. Linear correlation coefficients between $\mathrm{Pb}, \mathrm{Cr}$ and $\mathrm{Ni}$ concentrations $(\mu \mathrm{g} / \mathrm{g})$, porosity, organic carbon (TOC, \%), total carbon (TC, \%), inorganic carbon (TIC, \%), C/N ratio, carbon stable isotope $\left(\delta^{13} \mathrm{C}\right.$, $\%$ ) and sediment compositions (fines, sand, clay, silt contents, \%). Statistically relevant coefficients are reported in bold and highly significant one in bold red.

\begin{tabular}{|c|c|c|c|c|c|c|c|c|c|c|c|c|c|}
\hline & $\mathbf{P b}$ & $\mathrm{Cr}$ & $\mathrm{Ni}$ & Porosity & TOC & TC & TIC & $\mathrm{C} / \mathrm{N}$ & $\delta^{13} \mathrm{C}$ & Fines & Sand & Silt & Clay \\
\hline $\mathrm{Pb}$ & 1.00 & & & & & & & & & & & & \\
\hline $\mathrm{Cr}$ & -0.04 & 1.00 & & & & & & & & & & & \\
\hline $\mathrm{Ni}$ & 0.12 & 0.67 & 1.00 & & & & & & & & & & \\
\hline Porosity & -0.69 & 0.43 & 0.06 & 1.00 & & & & & & & & & \\
\hline TOC & 0.10 & 0.09 & 0.30 & -0.10 & 1.00 & & & & & & & & \\
\hline $\mathrm{TC}$ & -0.04 & -0.16 & -0.72 & 0.09 & -0.52 & 1.00 & & & & & & & \\
\hline TIC & -0.06 & -0.16 & -0.70 & 0.10 & -0.64 & 0.99 & 1.00 & & & & & & \\
\hline $\mathrm{C} / \mathrm{N}$ & -0.03 & 0.04 & 0.07 & 0.12 & 0.59 & -0.29 & -0.36 & 1.00 & & & & & \\
\hline$\delta^{13} \mathrm{C}$ & -0.13 & 0.07 & -0.17 & 0.20 & -0.82 & 0.40 & 0.50 & -0.56 & 1.00 & & & & \\
\hline fines & 0.09 & 0.19 & 0.68 & -0.11 & 0.70 & -0.89 & -0.92 & 0.45 & -0.59 & 1.00 & & & \\
\hline Sand & -0.10 & -0.21 & -0.67 & 0.08 & -0.73 & 0.87 & 0.91 & -0.48 & 0.62 & -1.00 & 1.00 & & \\
\hline Silt & 0.12 & -0.17 & 0.31 & -0.39 & 0.24 & -0.60 & -0.58 & 0.18 & -0.45 & 0.67 & -0.63 & 1.00 & \\
\hline Clay & -0.05 & 0.42 & 0.24 & 0.42 & 0.40 & -0.07 & -0.13 & 0.23 & -0.02 & 0.10 & -0.15 & -0.67 & 1.00 \\
\hline
\end{tabular}

These results allow us to hypothesize that the input material from the NR is quickly moved northward by marine currents and released not far from the river mouth, particularly in the area near and along the coast (north of the river mouth). The observed organic carbon distribution highlights a reduced fluvial influence moving seaward. However, surficial sediments may be affected by seasonal 
conditions and their distribution may be different in other periods of the year due to different amounts of input material from the river.

\subsection{Age Model and Sediment Accumulation Rates}

Activity-depth profiles of ${ }^{137} \mathrm{Cs}$ and ${ }^{210} \mathrm{~Pb}$ were evaluated along the $\mathrm{BC}$ s to define an age model of the NC recent sedimentary sequence (Figure 3 ).

Correlations between ${ }^{210} \mathrm{~Pb}$ age determinations and depth are strongly model-dependent in cores with non-exponential ${ }^{210} \mathrm{~Pb}$ profiles [46]. Assuming a constant ${ }^{210} \mathrm{~Pb}$ flux below the surficial mixed layer, a "constant flux-constant sedimentation" model has been adopted to obtain an estimate of sedimentation accumulation rates (SARs) for the last hundred years. However, since the main assumptions of most common conceptual models in sediment chronologies refer to the inputs of particles and/or a radiotracer onto the sediment, in those samples where ${ }^{210} \mathrm{~Pb}$ profiles were not suitable for model calculations (such as in samples $06 \mathrm{BC}$ and 10BC), rough estimates of sediment accumulation rates were obtained by assuming an age of 100 years at the depth where the ${ }^{210} \mathrm{~Pb}$ background value of $\approx 18 \mathrm{~Bq} / \mathrm{kg}$ is found (Figure 3d,e). Since physical mixing and bioturbation were neglected in the calculations, these apparent average rates have to be considered upper limits.

Since the ${ }^{210} \mathrm{~Pb}$ dating model requires validation by a second, independent stratigraphic tracer $[47,48],{ }^{137} \mathrm{Cs}$ activity-depth profiles were considered in the calculations. Unfortunately, as mentioned above, the $1986{ }^{137}$ Cs peak (Chernobyl accident) is not cleatracer [47,48]rly identifiable in the investigated sedimentary intervals. This is probably due to the strong bioturbation and sediment mixing (see X-ray images in Figure 3f,g) as suggested before by [16]. Moreover, since the half-life of ${ }^{137} \mathrm{Cs}$ is 30.17 years, it could not be excluded that the concentration is below the experimental sensitivity. This effect may be enhanced in case of high contents of carbonate (such as in karstic areas) that are less reactive to radiotracers [49]. In order to overcome validation troubleshooting, the core depth where ${ }^{137} \mathrm{Cs}$ reached the instrumental detection limit was used as reference age, assuming it corresponded to the early 1960s, when a large number of nuclear bombs were exploded in the atmosphere.

Estimated sediment accumulation rates (SARs; Figure 6) range from 1.9 to $8.5 \mathrm{~mm} / \mathrm{yr}$. These values differ partially from those previously estimated by other authors [16], ranging from 4 to $6 \mathrm{~mm} / \mathrm{yr}$ and based only on the distribution of ${ }^{137} \mathrm{Cs}$ in core sediments. In particular, the lowest SAR value of $1.9 \mathrm{~mm} / \mathrm{yr}$ was found at site 06BC (Figure 6), located to the NW of the channel at the boundary with the Korcula Channel, a location comparable to that of sample K3 of [16] where a SAR of $4 \mathrm{~mm} / \mathrm{yr}$ was estimated. In the sectors of the channel less influenced by the river outflow, SARs range from 1.9 to $2.3 \mathrm{~mm} / \mathrm{yr}$, while in the areas where the river influence is high, SARs range from 4.0 to $8.5 \mathrm{~mm} / \mathrm{yr}$. The highest accumulation rates are observed in front of the river mouth and along the northeastern coast with a peak of localized preferential accumulation at site 04BC ( $8.5 \mathrm{~mm} / \mathrm{yr}$; Figure 6). Estimated accumulation rates are in agreement with the observed water circulation, where a hysopycnal river plume formed at the river mouth distributes particles toward the open sea. 


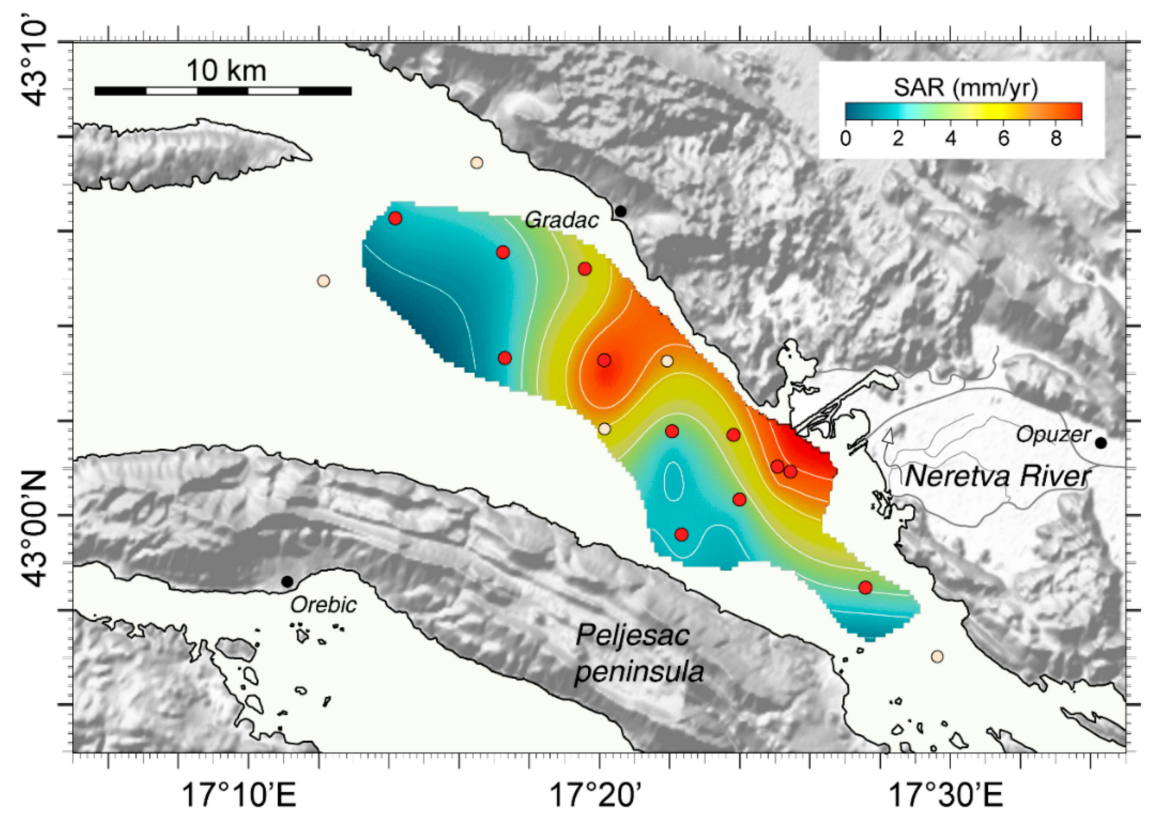

Figure 6. Apparent sediment accumulation rates (SAR) over the study area.

Apparent accumulation rates (Figures 3 and 6) suggest that most surficial sediments in the NC result from the present day seasonally river-dominated coastal sedimentary regime, with few relict deposits in its southernmost sector, south of the river mouth. According to the calculated SARs, our $\mathrm{BC}$ s record a time interval ranging from 18 (04BC) to 100 years (06BC) ago.

\subsection{Regional Water Circulation and Water-Column Physical Properties}

Surficial currents along the eastern Adriatic in the proximity of the NC are always oriented from $\mathrm{SE}$ to NW following the overall cyclonic circulation of the basin [50]. Local data on annual mean values of water circulation within the NC are not available in the literature, except for a little punctual information. Given that the NC represents a semi-closed marine environment, it is reasonable to assume that channel hydrodynamics are the result of a balance between tidal currents and fluvial influence, and seasonal variations in precipitation may act as a driving factor for the regional water exchange with the Adriatic open sea.

Generally, river currents do not exceed the velocity of $0.1 \mathrm{~m} / \mathrm{s}$ and are higher during the winter season [51,52]. In particular, in 2004, daily outflows $\left(\mathrm{m}^{3} / \mathrm{s}\right)$ during winter and spring periods ranged from 300 to $400 \mathrm{~m}^{3} / \mathrm{s}$, with short time intervals of peak flow $\left(>500 \mathrm{~m}^{3} / \mathrm{s}\right)$ or reduced flow $\left(<200 \mathrm{~m}^{3} / \mathrm{s}\right)$. However, during the summer season, the river outflow is drastically reduced (up to $50 \mathrm{~m}^{3} / \mathrm{s}$ ), as reported by UNEP/MAP [53]. In addition, horizontal distribution of freshwater into the channel may depend on the direction of local winds and may vary on a daily basis [54].

Based on CTD data, sediment grain size and SAR surficial distributions, we suggest the presence of an eddy in the NC waters located at the center of the channel that may strongly influence sediment dispersion and determine areas of localized preferential sediment accumulation not necessarily in correspondence with the river mouth (e.g., 10BC, Figure 4). Moreover, a considerable amount of freshwater is discharged into the channel by several submarine karstic springs [55], suggesting high inflow of cold water that lacks sediment load during periods of intense rainfall.

The observed water stratification along the northern transect may represent a seasonal snapshot of the hydrologic conditions of the study area. Mixed-water conditions may dominate through the entire NC area during flooding events in autumn. However, for the objectives of this study, spring conditions may be considered the optimal hydrological situation. Close to the river mouth, less salty and colder water was detected. This could be due to a reduction of the salt-wedge during low tide conditions and/or intense river outflow, or the karstic characteristics of the region. Karstic fresh waters 
have generally poor or null suspended material contents, explaining why these inflows do not affect organic matter or metal distributions.

\subsection{Metal Distributions}

Metal concentrations suggest that the river outflow plays only a marginal role in $\mathrm{Pb}, \mathrm{Cr}$ and $\mathrm{Ni}$ surficial distributions (Figure 5). In detail, $\mathrm{Pb}$ shows the highest concentration at site 10BC located in the center of the channel and far from possible direct sources. This may be due to an event of local discharge or to a pulse in the transport of metal enriched sediment, as suggested by the higher sand content at the top of the core and by the N/C values (Figure 2b,c and Figure 3). A second local maximum of $\mathrm{Pb}$ content is located in front of the river mouth following a distribution inversely correlated with the distance from the mouth (Figure $5 \mathrm{a}$ ).

$\mathrm{Cr}$ and Ni contents (Figure $5 b, c$ ) are affected by a source located along the coast to the NW of the river mouth (close to station 08G). Moreover, $\mathrm{Cr}$ content shows another local maximum at site 07G $(70.4 \mu \mathrm{g} / \mathrm{g})$, where an increase in the sand fraction is observed, suggesting an additional source. On the other hand, the minimum values of $\mathrm{Ni}$ and $\mathrm{Cr}$ contents at site $06 \mathrm{BC}$ may indicate a scouring resuspension or not sedimentation, as suggested by the observed N/C values. In the southern part of the NC, where coarser sediments are located, an increase of $\mathrm{Cr}$ and $\mathrm{Ni}$ contents associated to a low organic carbon and to a low sediment accumulation rate of $2.3 \mathrm{~mm} / \mathrm{yr}$ (15BC; Figure 3) suggests that this zone acts as a trap for metal bearing particles. Alternatively, the $\mathrm{Cr}$ and $\mathrm{Ni}$ abundances in this area may be influenced by sediment inputs from Peljesac Peninsula.

Some authors indicate the ratio $\mathrm{Cr} / \mathrm{Ni}$ as a possible tracer of geo-genic versus anthropogenic influences [56-58] and suggest it as suitable to determining geochemical baselines in the case of high natural concentrations $[34,35,59]$. In particular, $\mathrm{Cr}$ concentrations in south Dalmatia show a mean value of $126 \mu \mathrm{g} / \mathrm{g}$; that is the highest value found in karstic regions, probably due to the presence of chromite-bearing ultramafic rocks and/or of clastic deposits derived from older mafic magmatic rocks. Similarly, Ni levels in the same area show a mean value as high as $84 \mu \mathrm{g} / \mathrm{g}$ as a consequence of the presence of mafic and ultramafic rock outcroppings in the region. These rocks are probably a source of $\mathrm{Ni}$ in alluvial soils of the floodplains of rivers draining this region [57]. The expected $\mathrm{Cr} / \mathrm{Ni}$ value reported in literature [56-58] is about 1.5, whereas in the study area $\mathrm{Cr} / \mathrm{Ni}$ ranges from 0.7 (site 12G) to 1.9 (site $07 \mathrm{G}$ ) with a mean value of 0.9 . This discrepancy may be due to a natural variability but also due to the extraction efficiency of the leaching method. However, ratio values are generally uniform in the area supporting the hypothesis of $\mathrm{Cr}$ and $\mathrm{Ni}$ background concentrations.

According to previous data [17], heavy metals (such as $\mathrm{Pb}, \mathrm{Cr}$ and $\mathrm{Ni}$ ) in surficial sediments are tightly linked to fine grain size fractions, and in particular, to clay minerals coated by iron oxides/oxy-hydroxides that may trap metal cations within their crystal-chemical structures. Univariate statistical analysis shown in Table 1 confirms the previous observations for $\mathrm{Ni}$ and $\mathrm{Cr}$ : that they correlate positively with each other, and with clay and porosity, while they correlate negatively with total and inorganic carbon. In addition, organic carbon shows a positive correlation with fine grain size, in particular, with the clay fraction, and negative ones with total carbon and inorganic carbon. These results may support the hypothesis of clay minerals and organic matter as driving factors of $\mathrm{Cr}$ and $\mathrm{Ni}$ areal distribution. $\mathrm{Pb}$ shows a different behavior, characterized by a negative significant correlation with porosity. Since porosity is correlated negatively to silt and positively to clay, this suggests that $\mathrm{Pb}$ is not immobilized in the clay fraction of the sediments having higher affinity with the silt fraction.

A preliminary evaluation of environmental risks due to contaminant loads within the channel has been carried out, comparing surficial concentration values with quality criteria for marine sediments (Table 2) - threshold effect level (TEL), effect range low (ERL), probable effect level (PEL) and effect range median (ERM) [60-62] — and with benchmarks (LCB and LCL) for Italian coastal areas [63]. These guidelines are screening tools to predict potential sediment toxicity, linking sediment metal concentrations to the adverse biological effects that may result from exposure to chemicals. 
Table 2. Minimum, maximum and average concentrations (in $\mu \mathrm{g} / \mathrm{g}$ d.w.) of heavy metals in box-core sediments. Comparison with Italian and international sediment quality guidelines benchmarks.

\begin{tabular}{cccc}
\hline & $\mathbf{C r}$ & $\mathbf{N i}$ & $\mathbf{P b}$ \\
\hline Mean surficial concentration & 56.3 & 58.2 & 25 \\
Minimum & 26.9 & 28.7 & 4.5 \\
Maximum & 84 & 86.8 & 67.9 \\
BG & 45 & 51.8 & 24 \\
WA & 100 & 40 & 10 \\
LCB $^{*}$ & 100 & 70 & 40 \\
LCL $^{*}$ & 360 & 75 & 70 \\
ERL $^{* *}$ & 81 & 20.9 & 46.7 \\
ERM $^{* *}$ & 370 & 51.6 & 218 \\
ISQGs $^{* *}$ & 52.3 & 15.9 & 30.2 \\
PEL $^{* *}$ & 160 & 42.8 & 112.2 \\
\hline
\end{tabular}

Mean metal concentrations pre-seventies (BG); world average (WA) [64]; * Italian Sediment Quality benchmark: APAT and ICRAM [63]; ** International Sediment Quality Guidelines [60-62].

The $\mathrm{Pb}$ and $\mathrm{Cr}$ levels in surficial samples are below the benchmarks of PEL, ERM, and the Italian LCL guidelines, except at sites 10BC and 14BC for Pb (ERL and LCB) and 08G for Cr (ERL). However, the incidence of the effect for these samples may be considered low or scarcely probable $(8 \%-30 \%$ for $\mathrm{Pb}$ and $2.9 \%-21.1 \%$ for $\mathrm{Cr}$; [62-64]).

The Ni surficial concentration exceeds, at several sites, both PEL and ERM guidelines, whereas stations 06BC and 07G and 10BC comply under PEL; however, the Italian benchmark LCB is exceeded only at site 08G. In general, the effect incidence for exceeding ERM is common, although for $\mathrm{Ni}$ it is only $16.9 \%$ [62-64]. The $\mathrm{Pb}, \mathrm{Cr}$ and Ni concentrations in surficial sediments of the Neretva Channel fall into an unpolluted class with exception of $\mathrm{Pb}$ content of sample 10BC falling into a moderately polluted class. All this highlights a general unpolluted situation of the channel.

The sediment flux (carried out where BCs were available; Figure 7) provides a quantitative estimation of the amount of material that deposits in the channel. Two areas of higher flux are identified: in front the river mouth and in the center of the NC, at site 04BC. The latter location is not related to any particular morphologic setting of the channel and coincides with the area where we suggest the presence of an eddy in the water circulation, probably favoring a critical area of accumulation. TOC, following a similar distribution, tells the same story (Figure 2b), given that TOC input depends mostly from the river inflow because springs water may be assumed containing very few particles. These observations document that local hydrology plays a key role in controlling the sediment distribution in the area. 


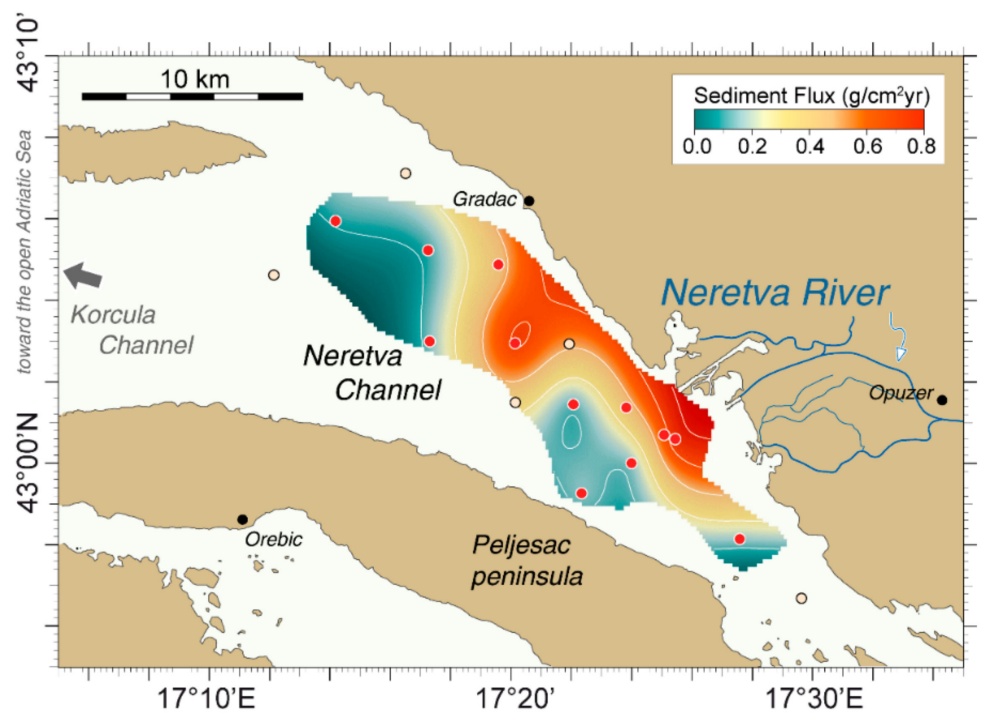

Figure 7. Areal distribution of sediment flux $\left(\mathrm{g} / \mathrm{cm}^{2} \mathrm{yr}\right)$ in surficial sediment of the Neretva Channel.

\section{Conclusions}

In this study, a multi-proxy approach on surficial sediment samples allowed us to determine sediment dynamics of the Neretva delta system, the largest modern siliciclastic depositional system on the eastern Adriatic coast.

Samples from 12 box-corer and five grab stations document that surficial sediments are predominantly clayey silt and coarse silt with a distribution of finer grained particles decreasing southward moving away from the river mouth.

Estimated accumulation rates, based on ${ }^{210} \mathrm{~Pb}$ and ${ }^{137} \mathrm{Cs}$ activity versus depth profiles, range from 1.9 to $8.4 \mathrm{~mm} / \mathrm{yr}$, suggesting the center of the channel and the river mouth as the sectors with the highest sediment deposition rates. In particular, two areas of higher sediment accumulation were identified: (i) close to the river mouth; and (ii) in the central-northern sector of the Neretva Channel along the axis of the basin.

Temperature and salinity vertical distributions indicate stratified waters along the axis of the basin close to the Croatian coast, and the presence of less salty and colder water in the proximity of the river mouth. The latter consideration, together with the observation of strong salt intrusions in the NR delta, suggests a salt wedge reduction during low tide conditions and submerged fresh water inputs. Moreover, relationships between TOC and TN and their spatial distribution, in particular, covariations between $\mathrm{N} / \mathrm{C}$ and $\delta^{13} \mathrm{C}$, indicate a terrestrial origin with prevalent accumulation in the vicinity of the river mouth that decreases northward towards the open sea. The scenario depicted above agrees with temperature and salinity data of the water column and their surficial distribution in the channel.

Finally, based on CTD data, grain size, TOC and SAR distributions, we suggest the presence of an eddy in the NC waters near the center of the channel that may be triggered and/or intensified seasonally. This may strongly affect sediment dispersion favoring areas of localized preferential sediment accumulation not necessarily close to the river mouth (e.g., 10BC, Figure 4).

The distribution of $\mathrm{Pb}$ contents in the surficial sediments follows a general trend inversely proportional to the distance of the river mouth with two local zones of accumulation: in front of the river mouth and in the center of the channel. Univariate statistics indicate that $\mathrm{Pb}$ is not immobilized in the clay fraction. On the contrary, $\mathrm{Ni}$ and $\mathrm{Cr}$ distributions indicate that they follow the clay fraction and that they account for other sources besides the river, such as sediment input from the Peljesac peninsula. The comparison with marine sediment guidelines shows that surficial concentrations of the examined metals have a low toxicity. 
Author Contributions: F.G. had the role of project administrator and investigator in this study. S.R. wrote the preliminary version of the manuscript with the support of F.G. and the other authors. The methodology and validation of data were carried out by S.A., L.C. and M.L. F.C. reviewed and edited text and figures, and curated data. All authors discussed the results and contributed to the final manuscript. M.R. supervised the scientific project and provided financial support for the scientific work and publication. All authors have read and agreed to the published version of the manuscript.

Funding: Funds were provided, within the framework of ADRICOSM-NERES project (2006-2007) (Environmental regeneration and sustainable development of the delta of the NEretva river), by the Italian Ministry of Foreign Affairs and the Ecoss project Italy-Croatia (2019).

Acknowledgments: Thanks to Frano Matic, Grozdan Kuspilic and Slavica Matijevc of the Institute of Oceanography and Fisheries, Split Croatia; Gabriele Marozzi and Costante Luttazzi, for sample collection, sampling and treatment on R/V Bios; Mauro Frignani for helpful suggestions; and Nadia Pinardi for project coordination. Special thanks to Prof. Enrico Bonatti of Earth Institute Lamont-Doherty Earth Observatory, Columbia University for the careful english language revision of the manuscript. This is contribution number 2022 of the Istituto Di Scienze Marine of the Consiglio Nazionale delle Ricerche, Bologna.

Conflicts of Interest: The authors declare no conflict of interest. The funders had no role in the design of the study, in collection, analyses, or interpretation of the data; in the writing of the manuscript, or in the decision to publish the results.

\section{References}

1. UNEP/MAP 1995. Convention for the Protection of the Mediterranean Sea Against Pollution (Barcelona Convention) modified by Conference of Plenipotentiaries on the Convention for the Protection of the Mediterranean Sea against Pollution and its Protocols, held in Barcelona on 9 and 10 June 1995 (UNEP(OCA)/MED IG.6/7). Available online: https://ec.europa.eu/environment/marine/internationalcooperation/regional-sea-conventions/barcelona-convention/index_en.htm (accessed on 22 January 2020).

2. Directive 2000/60/EC of the European Parliament and of the Council of 23 October 2000 establishing a framework for Community action in the field of water policy (Water Framework Directive). OJ L 327, 22.12.2000, p. 1-73. Available online: http://data.europa.eu/eli/dir/2000/60/oj (accessed on 22 January 2020).

3. Directive 2008/56/EC of the European Parliament and of the Council of of 17 June 2008 establishing a framework for community action in the field of marine environmental policy (Marine Strategy Framework Directive). OJ L 164, 25.6.2008, p. 19-40. Available online: http://data.europa.eu/eli/dir/2008/56/oj (accessed on 22 January 2020).

4. Directive 92/43/EEC of 21 May 1992 on the conservation of natural habitats and of wild fauna and flora (Habitat Directive). Official Journal L 206, 22/07/1992 P. 0007 - 0050. Available online: http://data.europa.eu/ eli/dir/1992/43/oj (accessed on 22 January 2020).

5. Directive 2009/147/EC of the European Parliament and of the Council of 30 November 2009 on the conservation of wild birds (Bird Directive). OJ L 20, 26.1.2010, p. 7-25. Available online: http://data.europa.eu/eli/dir/2009/ 147/oj (accessed on 22 January 2020).

6. Van Hoey, G.; Borja, A.; Birchenough, S.; Buhl-Mortensen, L.; Degraer, S.; Fleischer, D.; Kerckhof, F.; Magni, P.; Muxika, I.; Reiss, H.; et al. The use of benthic indicators in Europe: From the Water Framework Directive to the Marine Strategy Framework Directive. Mar. Pollut. Bull. 2010, 60, 2187-2196. [CrossRef] [PubMed]

7. Micheli, F.; Levin, N.; Giakoumi, S.; Katsanevakis, S.; Abdulla, A.; Coll, M.; Fraschetti, S.; Kark, S.; Koutsoubas, D.; Mackelworth, P.; et al. Setting Priorities for Regional Conservation Planning in the Mediterranean Sea. PLoS ONE 2013, 8, e59038. [CrossRef] [PubMed]

8. Cattaneo, A.; Correggiari, A.; Langone, L.; Trincardi, F. The Late-Holocene Gargano subaqueous delta, Adriatic shelf: Sediment pathways and supply fluctuations. Mar. Geol. 2003, 193, 61-91. [CrossRef]

9. Sherwood, C.S.; Carniel, S.; Cavaleri, L.; Chiggiato, J.; Das, H.; Doyle, J.D.; Harris, C.K.; Niedoroda, A.W.; Pullen, J.; Reed, C.W.; et al. Sediment dynamics in the Adriatic Sea investigated with coupled models. Oceanography 2004, 17, 58-69. [CrossRef]

10. De Lazzari, A.; Rampazzo, G.; Pavoni, B. Geochemistry of sediments in the Northern and Central Adriatic Sea. Estuar. Coast. Shelf Sci. 2004, 59, 429-440. [CrossRef]

11. Frignani, M.; Langone, L.; Ravaioli, M.; Sorgente, D.; Alvisi, F.; Albertazzi, S. Fine-sediment mass balance in the western Adriatic continental shelf over a century time scale. Mar. Geol. 2005, 222, 113-133. [CrossRef] 
12. Romano, S.; Langone, L.; Frignani, M.; Albertazzi, S.; Focaccia, P.; Bellucci, L.G.; Ravaioli, M. Historical pattern and mass balance of trace metals in sediments of the northwestern Adriatic Sea Shelf. Mar. Pollut. Bull. 2013, 76, 32-41. [CrossRef]

13. Goudeau, M.-L.S.; Grauel, A.-L.; Bernasconi, S.; De Lange, G.J. Provenance of surface sediments along the southeastern Adriatic coastoff Italy: An overview. Estuar. Coast. Shelf Sci. 2013, 134, 45-56. [CrossRef]

14. Lopes-Rocha, M.; Langone, L.; Miserocchi, S.; Giordano, P.; Guerra, R. Spatial patterns and temporal trends of trace metal mass budgets in the western Adriatic sediments (Mediterranean Sea). Sci. Tot. Environ. 2018, 599, 1022-1033. [CrossRef]

15. Jurina, I.; Ivanić, M.; Vdović, N.; Mikac, N.; Sondi, I. Mechanism of the land-sea interactions in the Neretva River delta (Croatia): The distribution pattern of sediments and trace element. Rapp. Comm. Int. Mer. Medit. 2010, 39, 35.

16. Jurina, I.; Ivanic, M.; Troskot-Corbic, T.; Barisic, D.; Vdovic, N.; Sondi, I. Activity concentrations and distribution of radionuclides in surface and core sediments of the Neretva Channel (Adriatic Sea, Croatia). Geol. Croat. 2013, 66, 143-150. [CrossRef]

17. Jurina, I.; Ivanic, M.; Vdovic, N.; Troskot-Corbic, T.; Lojen, S.; Mikac, N.; Sondi, I. Deposition of trace metals in sediments of the deltaic plain and adjacent coastal area (the Neretva River, Adriatic Sea). J. Geochem. Explor. 2015, 157, 120-131. [CrossRef]

18. Kljakovic-Gaspic, Z.; Bogner, D.; Ujevic, I. Trace metals (Cd, Pb, Cu, Zn and Ni) in sediment of the submarine pit Dragon ear (Soline Bay, Rogoznica, Croatia). Environ. Geol. 2009, 58, 751-760. [CrossRef]

19. Law, G.T.W.; Geissler, A.; Boothman, C.; Burke, I.T.; Livens, F.R.; Lloyd, J.R.; Morris, K. Role of nitrate in conditioning aquifer sediments for technetium bioreduction. Environ. Sci. Technol. 2010, 44, 150-155. [CrossRef] [PubMed]

20. Orlic, M.; Dadic, V.; Grbec, B.; Leder, N.; Marki, A.; Matic, F.; Mihanovic, H.; Paklar, G.B.; Pasaric, M.; Pasaric, Z.; et al. Wintertime buoyancy forcing, changing seawater properties, and two different circulation systems produced in the Adriatic. J. Geophys. Res. Ocean. 2006, 111, C03S07. [CrossRef]

21. Skoulikidis, N.T. The environmental state of rivers in the Balkans-A review within the DPSIR framework. Sci. Total Environ. 2009, 407, 2501-2516. [CrossRef]

22. EIA R E P O R T. Environmental Impact Assessment in the Neretva and Trebišnjica River Basin (NTRB); No. TF052845/GE-P084608: Sarajevo / Banja Luka, August 2006; p. 285. Available online: http://documents. banquemondiale.org/curated/fr/793041468104056146/pdf/E14680REVISED0ECA1EA1P084608.pdf (accessed on 22 January 2020).

23. Ivanković, A.; Petrović, D.; Ivanković, P.; Majstorović, J. Monitoring of water salinity of the lower river Neretva. Int. J. Ecosyst. Ecol. Sci. 2017, 2, 136-143.

24. Kralj, D.; Romic, D.; Romic, M.; Cukrov, N.; Mlakar, M.; Kontrec, J.; Barisic, D.; Sirac, S. Geochemistry of stream sediments within the reclaimed coastal floodplain as indicator of anthropogenic impact (River Neretva, Croatia). J. Soils Sediment. 2015, 16, 1150-1167. [CrossRef]

25. Calo, F.; Parise, M. Waste management and problems of groundwater pollution in karst environments in the context of a post-conflict scenario: The case of Mostar (Bosnia Herzegovina). Habitat Int. 2009, 33, 63-72. [CrossRef]

26. Berner, R.A. Authigenic mineral formation resulting from organic matter decomposition in modern sediments. Fortschr. Mineral. 1981, 59, 117-135.

27. Tesi, T.; Langone, L.; Goni, M.A.; Miserocchi, S.; Bertasi, F. Changes in the composition of organic matter from prodeltaic sediments after a large flood event (Po River, Italy). Geochim. Cosmochim. Acta 2008, 72, 2100-2114. [CrossRef]

28. Bellucci, L.G.; Frignani, M.; Cochran, J.K.; Albertazzi, S.; Zaggia, L.; Cecconi, G.; Hopkins, H. ${ }^{210} \mathrm{~Pb}$ and ${ }^{137} \mathrm{Cs}$ as chronometers for salt marsh accretion in the Venice Lagoon and links to flooding frequency and climate change. J. Environ. Radioactiv. 2007, 97, 85-102. [CrossRef] [PubMed]

29. Frignani, M.; Langone, L. Accumulation rates and ${ }^{137} \mathrm{Cs}$ distribution in sediments off the Po River Delta and the Emilia Romagna coast (north-western Adriatic Sea, Italy). Cont. Shelf Res. 1991, 11, 525-542. [CrossRef]

30. Bellucci, L.G.; Frignani, M.; Paolucci, D.; Ravanelli, M. Distribution of heavy metals in sediments of the Venice Lagoon: The role of the industrial area. Sci. Total Environ. 2002, 295, 35-49. [CrossRef] 
31. UNESCO. The Acquisition, Calibration and Analysis of CTD Data: Unesco Technical Papers in Marine Science 54; A Report of SCOR Working Group 51; United Nation Educational, Scientific and Cultural Organization: Paris, France, 1988; p. 102, ISSN 0503-4299.

32. Schlitzer, R. Ocean Data View. 2018. Available online: https://odv.awi.de (accessed on 22 October 2019).

33. Olea, R.A. Optimal contour mapping using universal kriging. J. Geophys. Res. 1974, 79, 695-702. [CrossRef]

34. Cabral Pinto, M.M.S.; Ferreira da Silva, E.A.; Silva, M.M.V.G.; Melo-Gonçalves, P. Heavy metals of Santiago Island (Cape Verde) top soils: Estimated background value maps and environmental risk assessment. J. Afr. Earth Sci. 2015, 101, 162-176. [CrossRef]

35. Cabral Pinto, M.M.S.; Ferreira da Silva, E.A.; Silva, M.M.V.G.; Melo-Gonçalves, P.; Candeias, C. Environmental risk assessment based on high-resolution spatial maps of potentially toxic elements sampled on stream sediments of Santiago, Cape Verde. Geosciences 2014, 4, 297-315. [CrossRef]

36. Ligi, M.; Bortoluzzi, G. PLOTMAP: Geophysical and geological applications of good standard quality cartographic software. Comput. Geosci. 1989, 15, 519-585. [CrossRef]

37. Wessel, P.; Smith, W.H.F. New, improved version of Generic Mapping Tools released. AGU Eos Trans. 2006, 79, 579. [CrossRef]

38. Folk, R.L.; Ward, W.C. Brazos River bar: A study in the significance of grain size parameters. J. Sediment. Petrol. 1957, 27, 3-26. [CrossRef]

39. Graham, M.C.; Eaves, M.A.; Farmer, J.G.; Dobson, J.; Fallick, A.E. A study of carbon and nitrogen stable isotope and elemental ratios as potential indicators of source and fate of organic matter in sediments of the Forth Estuary, Scotland. Estuar. Coast. Shelf Sci. 2001, 52, 375-380. [CrossRef]

40. Middelburg, J.J.; Nieuwenhuize, J. Carbon and nitrogen stable isotopes in suspended matter and sediments from the Schelde. Estuary Mar. Chem. 1998, 60, 217-225.

41. Ogrinc, N.; Fontolan, G.; Faganeli, J.; Covelli, S. Carbon and nitrogen isotope compositions of organic matter in coastal marine sediments (the Gulf of Trieste, N Adriatic Sea): Indicators of sources and preservation. Mar. Chem. 2005, 95, 163-181. [CrossRef]

42. Lamb, A.L.; Wilson, G.P.; Leng, M.J. A review of coastal palaeoclimate and relative sea-level reconstructions using delta C-13 and C/N ratios in organic material. Earth Sci. Rev. 2006, 75, 29-57. [CrossRef]

43. Gõni, M.A.; Gardner, L.R. Seasonal dynamics in dissolved organic carbon concentrations in a coastal water-table aquifer at the forest-marsh interface. Aquat. Geochem. 2003, 9, 209-232. [CrossRef]

44. Garcia-Garcia, A.; Orange, D.; Lorenson, T.; Radakovitch, O.; Tesi, T.; Miserocchi, S.; Berne, S.; Friend, P.L.; Nittrouer, C.; Normand, A. Shallow gas off the Rhone prodelta, Gulf of Lions. Mar. Geol. 2006, 234, $215-231$. [CrossRef]

45. Perdue, E.M.; Koprivnjak, J.F. Using the $\mathrm{C} / \mathrm{N}$ ratio to estimate terrigenous inputs of organic matter to aquatic environments. Estuar. Coast. Shelf Sci. 2007, 73, 65-72. [CrossRef]

46. Robbins, J.A. Geochemical and geophysical application of radioactive lead. In The Biogeochemistry of Lead in the Environment; Nriagu, J.O., Ed.; Elsevier: Amsterdam, The Netherlands, 1978; pp. 285-393.

47. Smith, J.N. Why should we believe ${ }^{210} \mathrm{~Pb}$ sediment geochronologies? J. Environ. Radioactiv. 2001, 55, 121-123. [CrossRef]

48. Kirchner, G. ${ }^{210} \mathrm{~Pb}$ as a tool for establishing sediment chronologies: Examples of potentials and limitations of conventional dating models. J. Environ. Radioact. 2011, 102, 490-494. [CrossRef]

49. Bellucci, L.G.; Frignani, M.; Lin, S.; Muntau, H. Accumulation and metal fluxes in the central Venice Lagoon during the last century. Chem. Ecol. 2005, 21, 425-439. [CrossRef]

50. Vilibic, I.; Book, J.W.; Paklar, G.B.; Orlic, M.; Dadic, V.; Tudor, M.; Martin, P.J.; Pasaric, M.; Grbec, B.; Matic, F.; et al. West Adriatic coastal water excursions into the East Adriatic. J. Mar. Syst. 2009, 78, S132-S156. [CrossRef]

51. Poulain, P.M. Adriatic Sea surface circulation as derived from drifter data between 1990 and 1999. J. Mar. Syst. 2001, 29, 3-32. [CrossRef]

52. Poulain, P.M. Tidal currents in the Adriatic as measured by surface drifters. J. Geophys. Res. Oceans 2013, 118, 1434-1444. [CrossRef]

53. UNEP/MAP. Riverine transport of sediments and pollutants to the Mediterranean Sea. MAP Tech. Ser. 2003, $141,1-111$.

54. Matic, F. Air-Sea Interaction in Split, Brac and Neretva Channel. Master's Thesis, University of Zagreb, Zagreb, Croatia, 2005. 
55. Vidjak, O.; Bojanic, N.; Kuspilic, G.; Gladan, Z.N.; Ticina, V. Zooplankton community and hydrographical properties of the Neretva channel (eastern Adriatic Sea). Helgol. Mar. Res. 2007, 61, 267-282. [CrossRef]

56. Amorosi, A.; Sammartino, I. Influence of sediment provenance on background values of potentially toxic metals from near-surface sediments of Po coastal plain (Italy). Int. J. Earth Sci. 2007, 96, 389-396. [CrossRef]

57. Miko, S.; Peh, Z.; Parika, M.A. Geokemijski atlas zapadne Hrvatske; Institut za Geologska Istrazivanja Fond strucne dok: Zagreb, Croatia, 2001; p. 22.

58. Mugnai, C.; Bertolotto, R.M.; Gaino, F.; Tiberiade, C.; Bellucci, L.G.; Giuliani, S.; Romano, S.; Frignani, M.; Albertazzi, S.; Galazzo, D. History and Trends of Sediment Contamination by Heavy Metals Within and Close to a Marine Area of National Interest: The Ligurian Sea off Cogoleto-Stoppani (Genoa, Italy). Water Air Soil Pollut. 2010, 211, 69-77. [CrossRef]

59. Cabral Pinto, M.M.S.; Silva, M.M.V.G.; Ferreira da Silva, E.A.; Dinis, P.A.; Rocha, F. Transfer processes of potentially toxic elements (PTE) from rocks to soils and the origin of PTE in soils: A case study on the island of Santiago (Cape Verde). J. Geochem. Explor. 2017, 183, 140-151. [CrossRef]

60. Long, E.R.; Macdonald, D.D.; Smith, S.L.; Calder, F.D. Incidence of Adverse Biological Effects within Ranges of Chemical Concentrations in Marine and Estuarine Sediments. Environ. Manag. 1995, 19, 81-97. [CrossRef]

61. Long, E.R.; Field, L.J.; MacDonald, D.D. Predicting toxicity in marine sediments with numerical sediment quality guidelines. Environ. Toxicol. Chem. 1998, 17, 714-727. [CrossRef]

62. Grimwood, M.J.; Dixon, E. Assessment of Risks Posed by List II Metals to Sensitive Marine Areas (SMAs) and Adequacy of Existing Environmental Quality Standards (EQSs) for SMA Protection. WRc Rep. Engl. Nat. 1997.

63. APAT; ICRAM. Manuale per la Movimentazione di Sedimenti Marini; Corsini, S., Onorati, F., Pellegrini, D., Eds.; Ministero per l'ambiente e la tutela del territorio e del mare: Rome, Italy, 2006; p. 72.

64. Förstner, U.; Wittmann, G.T.W. Metal Pollution in the Aquatic Environment, 2nd ed.; Springer: Berlin/Heidelberg, Germany, 1981; p. 486.

(C) 2020 by the authors. Licensee MDPI, Basel, Switzerland. This article is an open access article distributed under the terms and conditions of the Creative Commons Attribution (CC BY) license (http://creativecommons.org/licenses/by/4.0/). 